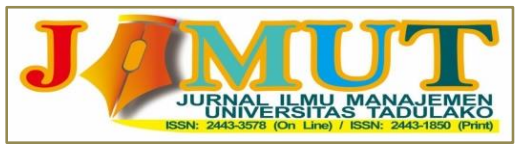

Vol. 6, No.3, September 2020, 252-260

\title{
ANALISIS PERBEDAAN RETURN DAN RISIKO DENGAN TANPA INCOME SMOOTHING PERUSAHAAN PERBANKAN BEI
}

\author{
WILDA YANTI \\ DJAYANI NURDIN \\ CICI RIANTY K. BIDIN \\ Program Studi Manajemen, Fakultas Ekonomi, Universitas Tadulako \\ Email: wilda.yanti075@gmail.com; djayani.nurdin@gmail.com; cicirianty@gmail.com
}

\begin{abstract}
Income Smoothing is a practice carried out by company managers in order to reduce reported fluctuations in profits and can have a beneficial effect on manager's performance appraisal. Many researchers believe that investors are more likely to invest their shares in companies whose earnings are relatively stable because to minimize stock risk. This research was conducted to see whether there is a difference between return and risk of shares in profit-seeking companies and not profitsharing.The samples in this study were 23 banking companies listed on the Indonesia Stock Exchange in the 2012-2016 period which were taken using purposive sampling method. The data analysis technique used is multiple linear regression and using the Eckel index model to find out which companies are doing income smoothing and not doing income smoothing.

The results of this study indicate that there is no significant difference between stock returns and risks in profit-seeking companies and non-profit firms in banking companies listed on the Indonesia Stock Exchange (IDX).
\end{abstract}

Keywords: return, risk, income smoothing.

\begin{abstract}
ABSTRAK
Income Smoothing merupakan praktik yang dilakukan oleh manajer perusahaan guna untuk mengurangi fluktuasi laba yang dilaporkan dan dapat memberi efek menguntungkan bagi penilaian kinerja manajer. Banyak peneliti percaya bahwa investor lebih cenderung menanamkan sahamnya pada perusahaan yang labanya relatif stabil karena untuk meminimalisir risiko saham. Penelitian ini dilakukan untuk melihat apakah terdapat perbedaan antara return dan risiko saham pada perusahaan perata laba dan bukan perata laba. Sampel dalam penelitian ini sebanyak 23 perusahaan perbankan yang terdaftar di Bursa Efek Indonesia periode 2012-2016 yang diambil menggunakan metode purposive sampling. Teknik analisis data yang digunakan yaitu regresi linear berganda dan mengunakan model indeks Eckel untuk mengetahui mana perusahaan yang melakukan perataan laba dan tidak melakukan perataan laba. Hasil penelitian ini menunjukkan bahwa tidak terdapat perbedaan secara signifikan antara return dan risiko saham pada perusahaan perata laba dan perusahaan bukan perata laba pada perusahaan perbankan yang terdaftar di Bursa Efek Indonesia (BEI).
\end{abstract}

Kata Kunci: return, risiko, perataan laba.

\section{PENDAHULUAN}

Perusahaan bisnis di Indonesia semakin nyata untuk bersaing secara terbuka dan bebas dalam menghadapi perdagangan global, sehingga menjadi pemicu yang kuat bagi manajemen perusahaan untuk menampilkan performa terbaik atas perusahaan yang dipimpinnya. Salah satu perusahaan yang dianggap cukup berperan penting dalam perekonomian yaitu perusahaan perbankan. Perusahaan perbankan sebagai suatu sektor yang cukup penting dalam perekonomian diharapkan dapat selalu menyajikan laporan keuangan guna memberikan informasi posisi keuangan maupun kinerja keuangan kepada pihak-pihak yang berkepentingan.

Laporan keuangan merupakan sarana pengkomunikasian informasi keuangan kepada pihak-pihak internal ataupun eksternal perusahaan (Putra dan Rahmanti, 2013). Laporan keuangan diharapkan dapat memberikan informasi kepada investor ataupun kreditor dalam mengambil keputusan terkait investasi dana mereka. 
Investasi yang dilakukan oleh investor salah satunya dengan membeli saham dari sebuah perusahaan dengan harga per lembar saham yang telah ditentukan oleh perusahaan yang bersangkutan. Berinvestasi dalam saham juga membawa sejumlah risiko antara lain tidak mendapatkan dividen dan capital loss. Terdapat istilah investasi yang menyebutkan High Risk - High Return dan Low RiskLow Return, artinya semakin tinggi return ekspektasi maka semakin tinggi risiko, begitu juga sebaliknya semakin rendah risiko semakin rendah juga return yang akan didapatkan. Investasi surat berharga seperti saham diyakini dapat menghasilkan keuntungan yang tinggi tetapi juga sangat berisiko. Oleh karena itu, investor harus mengetahui secara detail bagaimana kondisi dan kinerja perusahaan tersebut. Salah satu caranya dengan melihat laporan keuangan perusahaan.

Informasi besaran laba/rugi seringkali digunakan sebagai tolak ukur penilaian kinerja perusahaan, pihak internal maupun eksternal perusahaan terkadang dianggap hanya memusatkan perhatiannya pada laba yang diperoleh perusahaan tiap tahunnya tanpa mempertimbangkan prosedur akuntansi yang digunakan oleh manajemen seperti pencatatan mengenai aktivitas keuangan dan transaksi-transaksi yang dilakukan oleh perusahaan. Hal ini dapat menjadi dorongan manajemen untuk melakukan manajemen laba.

Manajemen laba menjadi menarik untuk diteliti karena dapat memberikan gambaran perilaku manajer dalam melaporkan infomasi keuangan pada periode tertentu.

Salah satu fenomena manajemen laba yang terjadi pada krisis global tahun 2008 di Indonesia yang menimpa Bank Century, dimana bank tersebut mengalami kesulitan likuiditas karena mengalami kalah kliring akibat adanya penarikan dana besar yang dilakukan nasabah potensial. Akibatnya, kalah kliring ini menimbulkan antrian panjang nasabah yang kesulitan mencairkan uangnya tersiar ke publik hingga menimbulkan signal negatif. Hal ini mengindikasikan adanya tindakan manajemen laba pada laporan keuangan Bank Century karena publik menyakini bahwa kondisi keuangan Bank Century tetap dalam keadaan baik, padahal tidaklah demikian.

Tindakan manajemen laba, yang umum digunakan oleh manajer adalah praktik perataan laba (income smoothing). Menurut Brayshaw dan Eldin (1989) perataan laba merupakan tindakan manajemen sukarela yang didorong oleh aspek perilaku didalam perusahaan dan lingkungannya serta kepuasan kelompok yang menjadi motivasi untuk melakukan perataan laba. Perataan laba dilakukan oleh manajer untuk mengurangi fluktuasi dari laba yang dilaporkan dan meningkatkan kemampuan investor untuk meramalkan arus kas dimasa akan datang. Pemilihan perataan laba (income smoothing) sebagai topik penelitian, dikarenakan tindakan perataan laba itu sendiri merupakan tindakan yang logis dan rasional (Jin dan Machfoedz, 1998).

Ada beberapa penelitian yang telah dilakukan sebelumnya, terdapat kontradiksi hasil penelitian mengenai perataan laba. Chandra (2009), menyimpulkan bahwa 25 perusahaan yang melakukan perataan laba tidak ditemukan adanya perbedaan return dan risiko saham antara perusahaan perata laba dan perusahaan bukan perata laba pada perusahaan manufaktur. Hal ini berbeda dengan hasil penelitian yang dilakukan oleh Putra dan Rahmanti (2013), yang menyimpulkan bahwa tidak terdapat perbedaan return saham antara perusahaan perata laba dan bukan perata laba, akan tetapi terdapat perbedaan pada risiko saham perusahaan perata laba dan bukan perusahaan perata laba pada perusahaan manufaktur.

\section{KAJIAN LITERATUR DAN PENGEMBANGAN HIPOTESIS}

\section{Manajemen Laba}

Manajemen laba (earnings management) adalah suatu konsep yang dilakukan perusahaan dalam mengelola laporan keuangan supaya laporan keuangan tampak terlihat memiliki kualitas (Putra dan Rahmanti, 2013). Scoot (2003) membagi manajemen laba dalam lima bentuk diantaranya: (1) Taking a bath, praktik ini dilakukan dengan cara menjadikan laba perusahaan pada periode berjalan menjadi sangat ekstrim rendah bahkan tinggi dibandingkan dengan laba periode sebelum dan sesudahnya. (2) 


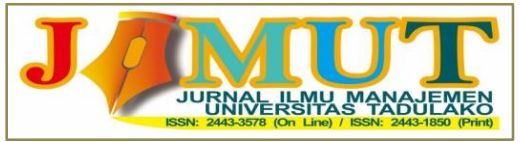

Vol. 6, No.3, September 2020, 252-260

Income minimization, praktik ini dilakukan ketika perusahaan mendapatkan laba yang tinggi, dengan tujuan agar tidak terkena dampak ekspektasi yang berlebihan dari berbagai pihak. (3) Income maximization, praktik ini dilakukan dengan tujuan untuk memperoleh bonus yang ditargetkan dengan cara menjadikan laba pada laporan keuangan periode berjalan lebih tinggi dari pada laba sebelumnya. (4) Income smoothing, praktik ini yang paling sering dilakukan oleh para manajer, yaitu dengan menaik-turunkan laba perusahaan dengan tujuan agar kinerja perusahaan terlihat stabil. (5) Timing Revenue dan Expenses Recognation, teknik ini dilakukan dengan membuat kebijakan tertentu yang berkaitan dengan timing suatu transaksi, misalnya pengakuan premature atas pendapatan.

\section{Agency Theory}

Jensen dan Meckling (1976) mendefinisikan hubungan keagenan sebagai sebuah kontrak antara satu orang atau lebih pemilik (prinsipal) yang menyewa orang lain (agent) untuk melakukan beberapa jasa atas nama pemilik yang meliputi pendelegasian wewenang pengambilan keputusan kepada agen, seperti investor memberikan wewenang pada manajer untuk mengelola perusahaan. Dalam Teori agensi hubungan kontrak antara pemilik (principal) dan manajer (agent) sulit tercipta karena adanya kepentingan yang saling bertentangan (Ansori dan Wahidahwati, 2014). Dalam hubungan antara agen dan prinsipal, akan timbul masalah jika terdapat informasi yang asimetri (information asymetry). Scoot (1997) menyatakan apabila beberapa pihak yang terkait dalam transaksi bisnis lebih memiliki informasi daripada pihak lainnya, maka kondisi tersebut dikatakan sebagai asimetri informasi.

\section{Signalling Theory}

Zuhrohtun dan Baridwan (2005) menyatakan bahwa "Teori signaling menjelaskan mengenai mengapa perusahaan mempunyai dorongan untuk memberikan informasi laporan keuangan kepada pihak eksternal, hal ini untuk mengurangi asimetri informasi". Pada saat informasi diumumkan, pelaku pasar terlebih dahulu menginterpretasikan dan menganalisis informasi tersebut sebagai signal baik (good news) atau signal buruk (bad news). Salah satu informasi yang dipublikasikan adalah laba perusahaan. Apabila laba yang dilaporkan oleh perusahaan meningkat maka informasi tersebut dapat dikategorikan sebagai sinyal baik karena mengindikasikan kondisi perusahaan yang baik. Sebaliknya apabila laba yang dilaporkan menurun maka perusahaan berada dalam kondisi tidak baik sehingga dianggap sebagai sinyal yang jelek. Dari penjelasan tersebut maka dapat disimpulkan bahwa perataan laba merupakan suatu signalling technique yang dimaksudkan untuk menyediakan sinyal dalam melakukan prediksi yang lebih akurat.

\section{Perataan Laba (Income Smoothing)}

Brayshaw dan Eldin (1989) mendefinisikan perataan laba adalah salah satu sarana yang dapat digunakan untuk mengurangi fluktuasi pelaporan penghasilan dan memanipulasi variabel-variabel (akuntansi) semu atau dengan melakukan transaksi-transaksi riil. Eckel (1981) menggolongkan perataan laba ke dalam dua tipe, yaitu perataan laba yang secara alami terjadi (naturally smooting) dan perataan laba yang secara sengaja dilakukan (intentionally smoothing). Adapun rumus perataan laba menurut Eckel (1981) dalam Putra dan Rahmanti (2013) adalah sebagai berikut:

$$
\text { Indeks Eckel }=\frac{\mathrm{CV} \Delta \mathrm{I}}{\mathrm{CV} \Delta \mathrm{S}}
$$

Dimana:

$$
\begin{aligned}
\mathrm{CV}= & \text { Coefficient Variation (Koefisien Variasi) didapat dari nilai deviasi standar dibagi nilai } \\
& \text { absolut } \text { expected value } \\
\Delta \mathrm{I}= & \text { Perubahan laba dalam satu periode } \\
\Delta \mathrm{S}= & \text { Perubahan Penjualan dalam satu periode }
\end{aligned}
$$

\section{Return}

Harjito dan Martono (2014), mendefinisikan return saham adalah tingkat pengembalian hasil yang diperoleh oleh para investor yang menanamkan atau menginvestasikan sejumlah dananya pada saham dalam periode tertentu. Return yang diperoleh dari investasi dapat berupa return realisasi yang telah terjadi atau return ekspektasi yang belum terjadi tetapi diharapkan terjadi dimasa akan datang. Return 
realisasi dihitung berdasarkan data historis. Return realisasi ini penting karena digunakan sebagai salah satu pengukur return ekspektasi dan risiko dimasa mendatang. Adapun rumus untuk menghitung Return sebagai berikut:

Dimana:

$$
\text { Return Total }=\frac{\mathrm{P}_{\mathrm{t}}-\mathrm{P}_{\mathrm{t}-1}}{\mathrm{P}_{\mathrm{t}-1}}
$$

$\mathrm{Pt}=$ Harga saham akhir periode

Pt-1 = Harga saham akhir periode (t-1)

\section{Risiko}

Risiko merupakan penyimpangan hasil (return) yang diperoleh dari rencana hasil (return) yang diharapkan, oleh karena itu apabila kita membicarakan risiko investasi saham berarti kita menganalisis kemungkinan tidak tercapainya hasil (keuntungan) yang diharapkan (Harjito dan Martono, 2014). Salah satu cara untuk menghitung risiko ialah dengan menggunakan model indeks tunggal (Single Indeks Model). Model ini diciptakan oleh William Sharpe dengan cara mengaitkan perhitungan return setiap aset pada return pasar. Adapun rumus model yang digunakan sebagai berikut:

Dimana:

$$
\mathrm{R}_{\mathrm{i}}=\alpha_{\mathrm{i}}+\beta_{\mathrm{i}} \mathrm{R}_{\mathrm{M}}+\mathrm{e}_{\mathrm{i}}
$$

$$
\begin{aligned}
& \mathrm{R}_{\mathrm{i}} \quad \text { = } \text { Harga saham akhir periode } \\
& \alpha_{\mathrm{i}} \quad \text { = Bagian return sekuritas } i \text { yang tidak dipengaruhi kinerja pasar } \\
& \beta_{\mathrm{i}} \quad \text { = Beta } \text { return sekuritas } i \text { terhadap perubahan return pasar } \\
& \mathrm{R}_{\mathrm{M}} \quad \text { = Return } \text { Pasar } \\
& \mathrm{e}_{\mathrm{i}} \quad \text { = Kesalahan residual }
\end{aligned}
$$

\section{Keterkaitan Antara Variabel}

\section{Return}

Return memiliki keterkaitan dengan risiko yang dimana apabila return meningkat makanya risiko yang didapatkan oleh perusahaan juga meningkat karena return dan risiko berbanding positif sehingga muncul istilah "High Risk - High Return" dan "Low Risk - Low Return".

\section{Risiko}

Apabila berinvestasi dalam saham tentu saja para investor mengetahui akan ada risiko yang akan diterima antara lain tidak mendapatkan dividen atau capital gain. Menurut Jogiyanto (2014) risiko sering dihubungkan dengan penyimpangan atau deviasi dari outcome yang diterima dengan yang diekspektasi.

\section{Perataan Laba}

Variabel berikutnya yaitu perataan laba, dalam hal ini perataan laba dapat dikatakan tindakan yang logis karena disamping perataan laba tersebut tidak menyalahi aturan akuntasi perataan laba juga merupakan salah satu cara untuk menarik investor untuk menanamkan sahamnya di perusahaan tertentu karena melihat laporan keuangannya yang stabil. Perataan laba juga mempunyai keterkaitan dengan return dan risiko yang dimana kedua variabel tersebut merupakan faktor yang mempengaruhi manajer untuk melakukan praktik laba.

\section{METODE PENELITIAN}

\section{Jenis Penelitian dan Sumber Data}

Penelitian ini menggunakan jenis penelitian deskriptif kuantitatif. Penelitian deskriptif menurut Sugiyono (2016) adalah penelitian yang dilakukan untuk mengetahui nilai variabel mandiri atau lebih (independen) tanpa membuat perbandingan atau menghubungkan antara variabel satu dengan variabel yang lainnya Kuantitatif menurut Sugiyono (2016) merupakan metode penelitian yang berlandaskan pada filsafat positivisme, digunakan untuk meneliti pada populasi atau sampel tertentu, pengumpulan 


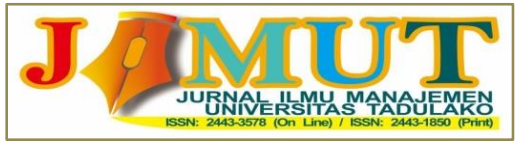

Vol. 6, No.3, September 2020, 252-260

data menggunakan instrumen penelitian, analisis data bersifat kuantitatif/statistik, dengan tujuan untuk menguji hipotesis yang telah ditetapkan.

Sumber data dalam penelitian ini adalah data sekunder. Menurut Indriantoro (2002) data sekunder adalah data penelitian yang diperoleh peneliti secara tidak langsung melalui media perantara (diperoleh dan dicatat oleh pihak lain). Data sekunder tersebut diperoleh dari situs resmi Bursa Efek Indonesia: www.idx.co.id.

\section{Populasi dan Sampel}

Populasi dalam penelitian ini adalah adalah perusahaan perbankan yang terdaftar di BEI. Teknik pengambilan sampel menggunakan purposive sampling. Sampel dalam penelitian ini adalah 22 perusahaan perbankan yang terdaftar di Bursa Efek Indonesia.

\section{Analisis Statistik Deskriptif}

Statistik deskriptif memberikan gambaran atau deskripsi suatu data yang dilihat dari nilai rata-rata (mean), standar deviasi, maksimum, minimum (Ghozali, 2005). Analisis statistik deskriptif dilakukan terhadap data rata-rata return dan risiko saham.

\section{Uji Normalitas}

Uji normalitas data dengan menggunakan One Sampel Kolmogorov-Smirnov test. KolmogorovSmirnov test merupakan suatu alat yang digunakan untuk melakukan uji normalitas data, yaitu apakah sampel berasal dari populasi yang berdistribusi normal atau tidak (Salno dan Baridwan, 2000). Pengujian ini dilakukan dengan menetapkan hipotesis sebagai berikut:

$\mathrm{H}_{1}$ : jika probabilitas sig $>0.05$, maka data berdistribusi normal

$\mathrm{H}_{2}$ : jika probabilitas sig $<0.05$, maka data tidak berdistribusi normal

\section{Uji F (Lavene)}

Uji F (uji Lavene) menurut Ghozali (2005) dilakukan untuk mengetahui apakah variance populasi kedua sampel tersebut sama (equal variances assumed) atau berbeda (equal variances not assumed). Pengujian dilakukan dengan menetapkan hipotesis yaitu:

$\mathrm{H}_{1}$ : Jika Probabilitas Sig $>0.05$ maka kedua varian populasi adalah sama

$\mathrm{H}_{2}$ : Jika Probabilitas Sig < 0.05 maka kedua varian populasi adalah tidak sama

\section{HASIL DAN PEMBAHASAN}

\section{Income Smoothing (Perataan Laba)}

Selama periode pengamatan penelitian tahun 2012 sampai 2016, jumlah perusahaan perbankan yang melakukan Income Smoothing (perataan laba) adalah sebanyak 16 perusahaan diantaranya AGRO, BBCA, BDMN, BJBR, BMRI, BNBA, BNGA, BNII, BTPN, BVIC, INPC, MAYA, MCOR, MEGA, NISP, dan PNBN, sedangkan perusahaan perbankan yang tidak melakukan perataan laba adalah sebanyak 6 perusahaan diantaranya BACA, BBKP, BBNI, BBRI, BBTN, dan BSIM.

Status perusahaan yang melakukan perata laba dan tidak melakukan perata laba dengan melihat nilai Indeks Eckel dapat ditunjukkan dengan nilai kurang dari satu untuk perusahaan perata laba dan nilai lebih dari satu untuk perusahaan yang tidak melakukan perata laba. Apabila nilai kurang dari satu dinyatakan melakukan perataan laba ini berarti fluktuasi penjualan (sale) lebih besar dari income (laba) maka laba lebih smooth dari penjualan. Begitupun sebaliknya untuk nilai lebih dari satu dinyatakan tidak melakukan perataan laba karena fluktuasi income lebih besar dari penjualan dan ini berarti tidak smooth dan lebih berisiko.

Status perusahaan yang melakukan perata laba dan tidak melakukan perata laba dengan melihat nilai Indeks Eckel dapat ditunjukkan dengan nilai kurang dari satu untuk perusahaan perata laba dan nilai lebih dari satu untuk perusahaan yang tidak melakukan perata laba. Apabila nilai kurang dari satu dinyatakan melakukan perataan laba ini berarti fluktuasi penjualan (sale) lebih besar dari income (laba) maka laba lebih smooth dari penjualan. Begitupun sebaliknya untuk nilai lebih dari satu dinyatakan tidak melakukan perataan laba karena fluktuasi income lebih besar dari penjualan dan ini berarti tidak smooth dan lebih berisiko. 


\section{Analisis Statistik Deskriptif}

Data yang digunakan dalam penelitian ini sebanyak 22 sampel. Return perata laba untuk nilai minimumya adalah sebesar -0.0413, dan maksimum sebesar 0.6692, mean sebesar 0.190500 dengan standar deviasi sebesar 0.2320821 , return bukan perata laba nilai minimumnya adalah sebesar 0.3396 , dan maksimum sebesar 0.9602, mean sebesar 0.171783 dengan standar deviasi sebesar 0.4269735.

Risiko perata laba menujukkan nilai minimum sebesar -3.0730, dan maksimum sebesar 0.4420 , mean sebesar -0.498250 dengan standar deviasi sebesar 0.9814249 , untuk risiko bukan perata laba nilai minimumnya adalah sebesar -0.9940 , dan maksimum sebesar 0.2310 , mean sebesar -0.178500 dengan standar deviasi sebesar 0.4536672 .

\section{Pengujian F (Uji Lavene)}

Pengujian terhadap kesamaan (homogenitas) varians harus dilakukan sebelum melakukan pengujian hipotesis. Pengujian akan dilakukan pada data yang berdistribusi normal. Pengujian ini dilakukan untuk menentukan apakah pengujian hipotesis menggunakan asumsi varians sama (equal variances assumsed) atau menggunakan varians tidak sama (equal variances not assumsed). Berikut hasil pengujian $\mathrm{F}$ (Uji Lavene):

uji $\mathrm{F}$ menunjukan nilai signifikansi untuk kedua variabel baik return maupun risiko adalah lebih besar dari 0,05 . Ini berarti $\mathrm{H}_{1}$ gagal ditolak dan disimpulkan bahwa rumus pengujian hipotesis menggunakan asumsi varians sama (equal variances assumsed).

\section{Pengujian Hipotesis}

\section{Uji Dua Sampel Independen}

Hipotesis pertama menyatakan bahwa tidak terdapat perbedaan antara rata-rata return dan risiko perusahaan perata laba dan perusahaan bukan perata laba di perusahaan perbankan yang terdaftar di Bursa Efek Indonesia. Sedangkan hipotesis kedua menyatakan terdapat perbedaan antara rata-rata return dan risiko perusahaan perata laba dan perusahaan bukan perata laba di perusahaan perbankan yang terdaftar di Bursa Efek Indonesia. Setelah diketahui rata-rata return dan risiko perusahaan perata laba dan bukan perata laba, selanjutnya dilakukan uji dua sampel independen hasilnya dapat dilihat pada tabel dibawah ini:

\section{Tabel 1}

Hasil Uji Dua Sampel Independen Rata-rata Return dan Risiko Perusahaan Perata Laba dan Perusahaan Bukan Perata Laba Pada Perusahaan Perbankan

\begin{tabular}{|c|c|c|c|c|c|}
\hline $\begin{array}{c}\mathrm{N} \\
\mathrm{o}\end{array}$ & Variabel & t-hitung & $\begin{array}{c}\text { Asymp. } \\
\text { Sig } \\
(2-\text { Tailed })\end{array}$ & $\alpha$ & Keputusan \\
\hline 1 & Return & 0,133 & 0,895 & 0,05 & $\mathrm{H}_{1}$ gagal ditolak \\
\hline 2 & Risiko & $-0,759$ & 0,457 & 0,05 & $\mathrm{H}_{1}$ gagal ditolak \\
\hline
\end{tabular}

Sumber: Data diolah penulis, (2019)

Tabel 1 menunjukkan hasil uji beda return dan risiko perusahaan perata laba dan bukan perusahaan perata laba. Dari tabel tersebut diperoleh t hitung return sebesar 0,133 dan risiko sebesar -0,759. Sedangkan nilai signifikansi return sebesar 0,895 dan risiko sebesar 0,457 yang berarti lebih besar dari alpha $(0,895>0,05)$ dan $(0,457>0,05)$. Dengan demikian dapat disimpulkan bahwa tidak terdapat perbedaan return dan risiko saham pada perusahaan perata laba dan bukan perusahaan perata laba, sehingga hipotesis pertama $\left(\mathrm{H}_{1}\right)$ diterima dan hipotesis kedua $\left(\mathrm{H}_{2}\right)$ ditolak.

\section{Pembahasan}

\section{Hipotesis Pertama}




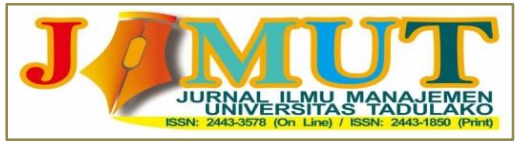

Vol. 6, No.3, September 2020, 252-260

Pengujian terhadap hipotesis pertama, secara statistik tidak ditemukan adanya perbedaan antara return perusahaan perata laba dan return perusahaan bukan perata laba pada perusahaan perbankan yang terdaftar di BEI, sehingga hipotesis yang menyatakan bahwa terdapat perbedaan return saham perusahaan perata laba dan perusahaan bukan perata laba ditolak $\left(\mathrm{H}_{1}\right.$ ditolak). Berdasarkan Tabel 5 menunjukkan hasil uji beda return perusahaan perata laba dan bukan perusahaan perata laba. Dari tabel tersebut diperoleh t hitung return sebesar 0.133 sedangkan nilai signifikansi return sebesar 0.895 yang berarti lebih besar dari alpha $(0.895>0.05)$ yang menunjukkan bahwa tidak terdapat perbedaan return saham antara perusahaan perata laba dan perusahaan bukan perata laba.

Return saham perusahaan perata laba dari tahun 2012-2016 cenderung berfluktuasi dengan selisih angka yang cukup jauh, begitu juga dengan perusahaan bukan perata laba. Dari hasil pengolahan data return saham diperoleh hasil rata-rata return saham perusahaan perata laba sebesar 0,1905 dan ratarata return saham perusahaan bukan perata laba sebesar 0,17178. Dari kedua perbandingan ini dapat diketahui bahwa rata-rata return saham perusahaan perata laba lebih rendah dibandingkan perusahaan bukan perata laba, akan tetapi perbedaan return kedua kelompok tidak berbeda secara signifikan.

Return perata laba lebih rendah dibanding return bukan perata laba dengan begitu fluktuasi harga saham tidak mencerminkan adanya perataan laba. Perbedaan return saham biasanya di sebabkan karena harga saham berfluktuasi. Harga saham yang berfluktuasi disebabkan oleh beberapa faktor seperti faktor fundamental, faktor teknikal, faktor ekonomi, sosial, dan politik, sehingga laba bukan merupakan satu-satunya faktor yang mempengaruhi terbentuknya harga saham dipasar modal. Dari penjelasan di atas maka dapat diduga bahwa pergerakan harga saham bukan satu-satunya yang ingin dicapai manajemen dalam melakukan perataan laba tetapi perataan laba diduga bertujuan lebih ke arah kepentingan perusahaan.

Hasil penelitian ini selaras dengan hasil penelitian sebelumnya yang dilakukan oleh Chandra (2009) yang menyatakan bahwa tidak terdapat perbedaan return saham antara perusahaan perata laba dan perusahaan bukan perata laba.

\section{Hipotesis Kedua}

Pengujian terhadap hipotesis kedua, secara statistik tidak ditemukan adanya perbedaan antara risiko saham perusahaan perata laba dan risiko saham perusahaan bukan perata laba di perusahaan perbankan yang terdaftar di BEI, sehingga hipotesis yang menyatakan bahwa terdapat perbedaan risiko saham perusahaan perata laba dan perusahaan bukan perata laba ditolak $\left(\mathrm{H}_{2}\right.$ ditolak). Berdasarkan Tabel 5 menunjukkan hasil uji beda risiko saham perusahaan perata laba dan bukan perusahaan perata laba. Dari tabel tersebut diperoleh $\mathrm{t}$ hitung risiko sebesar -0.759 sedangkan nilai signifikansi risiko sebesar 0.457 yang berarti lebih besar dari alpha $(0.457>0.05)$ yang menunjukkan bahwa tidak terdapat perbedaan yang risiko saham antara perusahaan perata laba dan perusahaan bukan perata laba. Perusahaan yang telah melakukan perataan laba risiko sahamnya lebih kecil dibanding yang tidak melakukan perataan laba.

Risiko saham perusahaan perata laba dan perusahaan bukan perata laba diperoleh dari besarnya beta melalui model indeks tunggal. Dari hasil pengolahan data risiko saham diperoleh hasil rata-rata risiko saham perusahaan perata laba sebesar -0.49825 dan rata-rata risiko saham perusahaan bukan perata laba sebesar -0.1785. Dari kedua perbandingan ini dapat diketahui bahwa rata-rata risiko saham perusahaan perata laba lebih rendah dibandingkan perusahaan bukan perata laba, akan tetapi perbedaan risiko kedua kelompok tidak berbeda secara signifikan. Besar kecilnya risiko yang diperoleh perusahaan dapat dipengaruhi dari beberapa sumber risiko antara lain risiko suku bunga, risiko pasar, risiko inflasi, risiko nilai tukar mata uang, dan risiko negara. Hal-hal inilah yang membuat tidak terdapat perbedaan yang signifikan antara kelompok perusahaan perata laba dan bukan perata laba.

Hasil penelitian ini berbeda dengan penelitian sebelumnya yang dilakukan oleh Putra dan Rahmanti (2013) yang menyatakan bahwa terdapat perbedaan antara risiko perusahaan perata laba dan bukan perusahaan perata laba.

\section{KESIMPULAN DAN SARAN}

\section{Kesimpulan}


Berdasarkan analisis yang dilakukan, maka dapat diambil kesimpulan sebagai berikut: (1) Hasil penelitian menunjukkan bahwa dari 22 sampel perusahaan perbankan yang terdaftar di BEI selama periode 2012-2016, 16 diantaranya melakukan praktik perataan laba (income smoothing) dan 6 tidak melakukan praktik perataan laba (income smoothing). (2) Hasil pengujian hipotesis terhadap return dan risiko saham antara perusahaan perbankan perata laba dan perusahaan bukan perata laba, tidak ditemukan adanya perbedaan return dan risiko saham antara perusahaan perata laba dan perusahaan bukan perata laba sehingga tidak perlu dilakukannya income smoothing pada perusahaan perbankan karena tidak ada perbedaan antara yang melakukan dan tidak melakukan income smoothing. (3) Variabel akuntansi (laba) bukan variabel penentu harga saham untuk perusahaan perbankan.

\section{Saran}

Saran-saran yang dapat diberikan bagi investor, manajer perusahaan maupun peneliti selanjutnya adalah sebagai berikut: (1) Bagi investor bebas menanamkan sahamnya pada perusahaan yang melakukan perataan laba atau tidak melakukan perataan laba karena tidak terdapat perbedaan yang signifikan. Hanya saja, sebaiknya investor dapat lebih teliti melihat laporan keuangan perusahaan yang disajikan oleh manajer perusahaan dikarenakan terkadang manajer hanya mementingkan kepentingan pribadi dan kepentingan perusahaan. (2) Bagi manajer sebaiknya dapat menyajikan laporan keuangan sesuai dengan kondisi sebenarnya (actual conditions) sehingga kepentingan stakeholder dapat terpenuhi. Pihak manajer juga harus memperhatikan bahwa melakukan perataan laba dapat mengubah persepsi investor terhadap perusahaan tersebut. (3) Bagi peneliti selanjutnya diharapkan dapat mengklasifikasikan perataan laba ke dalam tipe-tipe perataan laba dan dapat mengembangkan penelitian ini dengan menambahkan variabel-variabel yang dapat mempengaruhi perataan laba (income smoothing) seperti kepemilikan saham, bonus plan, dan kebijakan dividen. Selain itu, peneliti selanjutnya juga dapat menambahkan jumlah sampel sehingga lebih banyak lagi dan juga dapat memasukkan perusahaan dari sektor lain seperti asuransi, manufaktur dan non manufaktur.

\section{REFERENSI}

Ansori, E.R dan Wahidahwati. 2014. "Analisis Faktor-Faktor yang Mempengaruhi Perataan Laba Pada Perusahaan Manufaktur yang Terdaftar di BEI”. Jurnal Ilmu dan Riset Akuntansi. Vol. 3, No.11.

Brayshaw, R. E., and A. E. K. Eldin. 1989. "The Smoothing Hypothesis and The Role of Exchange Differences". Journal of Business Finance and Accounting. 16(5).

Chandra Irwan. 2009. "Analisis Perbedaan Return dan Risiko Saham Dengan dan Tanpa Perataan Laba Pada Perusahaan Manufaktur yang Terdaftar di BEI". Jurnal Akuntansi Kontemporer. Vol. 1, No.2.

Eckel, N. 1981. The Income Smoothing Hypothesis Revisited. Abacus Vol. 17, No. 1: 28-40.

Ghozali, H. I. 2005. Aplikasi Analisis Mv!tivariate dengan Program SPSS. Edisi Ketiga. Semarang: Undip.

Indiantoro, N., dan B. Supomo. 2002. Metodologi Penelitian Bisinis Untuk Akuntasi \& Manajemen, Edisi Pertama. Yogyakarta: BPFE.

Jensen, M.C dan Meckling. 1976. "The Theory of The Firm: Manajerial Behaviour, Agency Cost, and Ownership Structure”. Journal of Financial and Economics. Vol 3, No.4.

Martono, dan Agus Harjito. 2014. Manajemen Keuangan. Edisi ke 2. Cetakan Keempat. Yogyakarta: Ekonisia.

Putra Dwi R.A dan Rahmanti Wiwin. 2013. "Return dan Risiko Saham Pada Perusahaan Perata laba dan Bukan Perata Laba”. Jurnal Dinamika Akuntansi. Vol. 5 No.1.

Scoot, William R. 1997. Financial Accounting Theory, 2nd Edition. Canada: Prentice Hall Inc. 


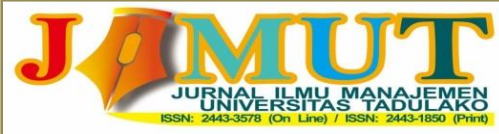

Vol. 6, No.3, September 2020, 252-260

Sugiyono. 2016. Metode Penelitian dan Pengembangan (Research and Development). Bandung; Alfab

Zuhrohtun, dan Zaki Baridwan. 2005. Pengaruh Pengumuman Peringkat terhadap Kinerja Obligasi.Simposium Nasional Akuntansi VIIISolo.Hlm.355. 